\title{
The value of Mental Index (MI) and Gonial Index (GI) in hypertension patients on its correlation with serum calcium and cortisol level
}

\author{
Dwi Putri Wulansari ${ }^{1} 2^{*}$, Lusi Epsilawati ${ }^{3}$ iD, \\ Farina Pramanik ${ }^{3}$, Suhardjo Sitam ${ }^{3}$ (iD
}

\section{ABSTRACT}

Objectives: This research was aimed to analyze the mandibular cortical width based on a mental index (MI) and gonial Index (GI) in hypertension patients correlated with serum calcium and cortisol levels.

Materials and Methods: This study was an analytic observational study with 31 hypertension patients aged 41-79. All of the patients have checked their serum calcium and cortisol level. The panoramic radiograph was taken and analyzed using Image-J Fiji software. The mandibular cortical width was then measured with Mental Index (MI) and Gonial Index (GI) and correlated with the serum calcium and cortisol level.
Results: The data obtained from examining serum calcium and cortisol levels and the measurement of Mental Index (MI) and Gonial Index (GI) showed varying results but tended towards normal values. The results of the correlation test between mental index and gonial index with cortisol and serum calcium showed no correlation with $\mathrm{p}>0.05$.

Conclusion: There was no correlation between serum calcium and cortisol level in the value of $\mathrm{MI}$ and $\mathrm{GI}$ in hypertension patients.
${ }^{1}$ Department of Oral and Maxillofacia Radiology, Faculty of Dentistry, Universitas Hasanuddin, Makassar, Indonesia 90245

${ }^{2}$ Dentomaxillofacial Radiology Residency Program, Faculty of Dentistry, Universitas Padjadjaran, Bandung, Indonesia 40132

${ }^{3}$ Department of Dentomaxillofacial Radiology, Faculty of Dentistry, Universitas Padjadjaran, Bandung, Indonesia 40132

*Correspondence to:

Dwi Putri Wulansari

هiputriwulansari51@gmail.com

Received on: February 2021

Revised on: March 2021

Accepted on: April 2021

Keywords: Mental index, gonial index, hypertension, serum calcium, serum cortisol

Cite this article: Wulansari DP, Epsilawati L, Pramanik F, Sitam S. The value of Mental Index (MI) and Gonial Index (GI in hypertension patients on its correlation with serum calcium and cortisol level. Jurnal Radiologi Dentomaksilofasial Indonesia 2021;5(2)44-7. https://doi.org/10.32793/jrdi.v5i1.671

\section{INTRODUCTION}

Hypertension is an asymptomatic disease with high prevalence and has an incidence rate of $6-32 \%$ of the population worldwide. ${ }^{1}$ Several studies have shown that hypertension is influenced by age, gender, hormones, nutrition, and lifestyle. ${ }^{2-4}$ One of the nutrients that can affect hypertension is the disruption of body calcium metabolism. ${ }^{1,2,5-7}$ Based on previous studies, there are two effects of the alteration in calcium levels on hypertension. If the calcium level is reduced, then nothing can prevent the effects of $\mathrm{NaCl}$ in the blood and would increase the blood pressure. ${ }^{5}$ Whereas if the level of calcium in the blood increases, the peripheral vessels resistance would also increase and lead to hypertension. ${ }^{7}$ Various previous studies have shown an association between hypertensive conditions and calcium metabolism disorders. ${ }^{8-11}$ In a different way from the calcium mechanism, cortisol levels can also affect hypertension in a patient. From several studies conducted by Carrol et.al Whitworth et.al, Xiujuan et.al found an increase in hypertensive patients' serum cortisol. ${ }^{12-14}$

Hypertension are the most common diseases in the elderly. They can be seen in some of the results of previous studies which reported a relationship between hypertension and bone mineral density. ${ }^{15}$

17 From Hisashi's study, it was found that there was a decrease in bone mineral density in hypertensive patients compared to the control group. ${ }^{18}$ Hypertension share a similar etiopathology that involves a genetic base and the influence of various nongenetic factors. The most relevant etiological factors for hypertension are low calcium intake and level, vitamin D and vitamin K deficiency, high sodium salt consumption, and low or very high nitric oxide levels. The reduction of bone mineral density (BMD) is related to hypertension, and it seems to be one of the major cardiovascular risk factors for fractures. ${ }^{19}$ In the present study we analyzed the mandibular cortical width based on a mental index (MI) and gonial Index (GI) in hypertension patients correlated with serum calcium and cortisol levels since both $\mathrm{MI}$ and $\mathrm{Gl}$ is the most common region to perform the measurement of cortical thickness at the mental foramen area in panoramic radiograph.

\section{MATERIALS AND METHODS}

This study was an observational analytic study and conducted at Dental Hospital of Padjadjaran University. The involved sample in this study was 31 hypertensive patients with an age range of 41-79 
years.

The calcium levels (calcium normal value: 8.4$10.2 \mathrm{ml} / \mathrm{l}$ ) and serum cortisol levels were examined (cortisol normal value: 3.7-19.4 ml/l). The panoramic radiograph was taken using Auto Zero Panoramic (Asahi Roentgen Ind.Co.,Ltd., Kyoto, Japan) with the following exposure parameters: 70 $\mathrm{kVp}, 10 \mathrm{~mA}$ and $12 \mathrm{sec}$. The radiograph obtained was analyzed using Image-J software (FIJI 1.46r for Windows). The morphometric measurements of the mandibular cortical thickness were carried out using Mental Index (MI) (normal value > 3.1) and Gonial Index (GI) (normal value >1.2).

In the measurement of the Gonial Index, two lines were drawn. One tangential to the posterior edge of the ramus and another tangential to the inferior border of mandibular. At the intersection of these two tangents, the angle was divided with a bisecting line. Measurements were made of cortica of the mandibular angle parallel to those bisecting lines (Figure.1a). For mental Index measurement (Figure 1b), we need to decide the mental foramen position. Then one tangent was drawn to the inferior of the mandibular border and another to the mandibular cortical upper line. Perpendicular to these two foramen. Cortical thickness was measured in parallel to this line.

The data was initially analyzed descriptively.
The normality of the data was verified with the Saphiro-Wilk test and the correlation was analyzed with Spearman Ranks correlation (SPSS, Inc., an IBM Company, version 25 for Windows).

\section{RESULTS}

The characteristics of the sample in this study was shown in Table 1 . There were more female patients $(67.74 \%)$ than male patients $(32.26 \%)$. The age range for the most samples was $46-55$ years (35.48\%). From Table 2, we could conclude that most of the hypertensive patients in this study had a normal level of calcium, cortisol, and also the normal value of Mental Index and Gonial Index, while Table 3 showed no correlation between calcium and cortisol levels with the value of Mental Index and Gonial Index since the $\mathrm{p}$-value was more than 0.05

\section{DISCUSSION}

The present study showed no significant difference in serum calcium in hypertensive patients, consistent with Kosch et al. in $2011^{20}$ and Hazari et al. in 2012. ${ }^{7}$ However, this finding was in
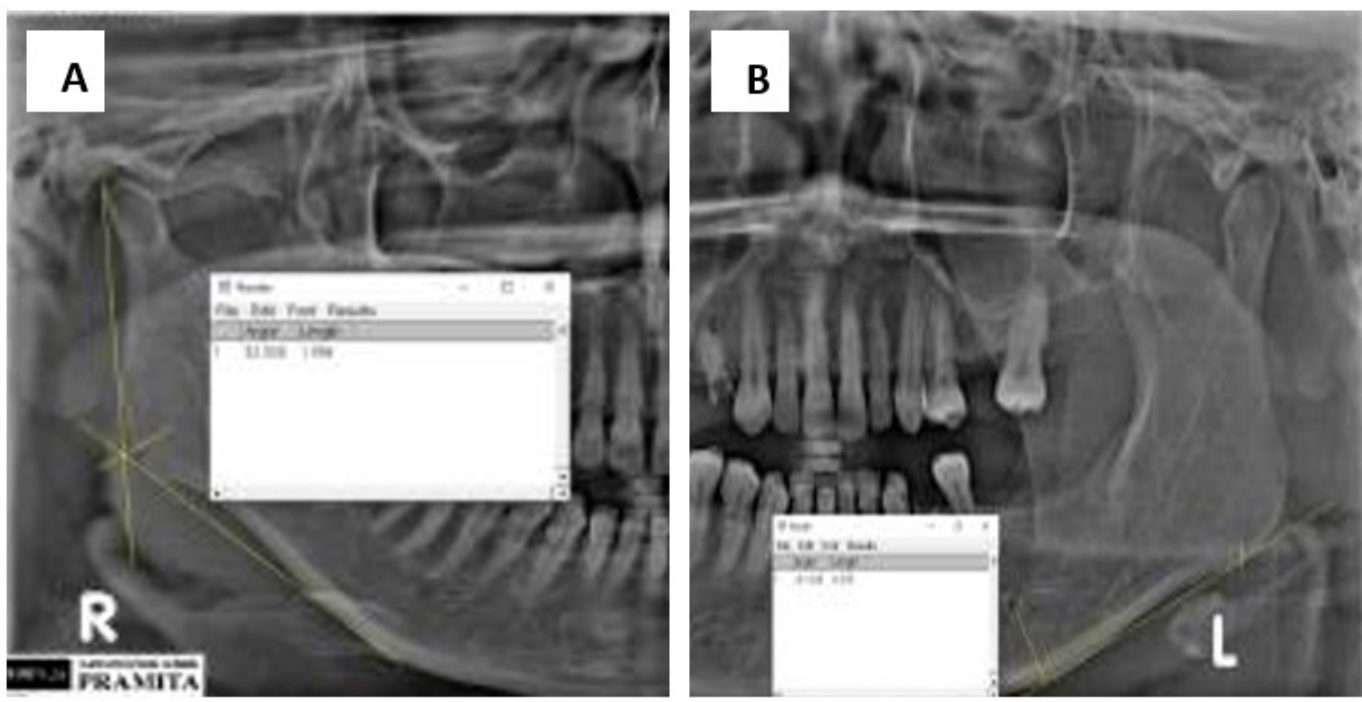

Figure 1. The measurement example of Gonial Index (a) and Mental Index (b) using Image-J Fiji software

Tabel 1. Characteristic of the patients

\begin{tabular}{ccccc}
\hline & \multicolumn{2}{c}{ Male } & \multicolumn{2}{c}{ Female } \\
\cline { 2 - 5 } Age (years) & $\mathbf{n}$ & $\%$ & $\mathbf{n}$ & $\%$ \\
\hline $36-45$ & 0 & 0 & 2 & 9.52 \\
$46-55$ & 3 & 30 & 8 & 38.09 \\
$56-65$ & 3 & 30 & 6 & 28.57 \\
$>65$ & 4 & 40 & 5 & 23.81 \\
Total & $\mathbf{1 0}$ & $\mathbf{1 0 0}$ & $\mathbf{2 1}$ & $\mathbf{1 0 0}$ \\
\hline
\end{tabular}


Table 2. Assessment of Calcium, Cortisol, Mental Index (MI) and Gonial Index (GI)

\begin{tabular}{lccc}
\hline & Minimal & Maximal & Mean \pm SD \\
\hline Calcium & 2 & 10.1 & $8.91 \pm 1.37$ \\
Cortisol & 0.8 & 14.8 & $7.52 \pm 3.41$ \\
Mental Index (MI) & 3.24 & 7.18 & $4.73 \pm 1.13$ \\
Gonial Index (GI) & 0.67 & 2.47 & $1.6 \pm 0.43$ \\
\hline
\end{tabular}

Table 3. Significant Value of Non-Parametric Correlations

\begin{tabular}{lcccc}
\hline Variable & \multicolumn{2}{c}{ Calcium level } & \multicolumn{2}{c}{ Cortisol level } \\
\cline { 2 - 5 } & Male & Female & Male & Female \\
\hline Mentale Index (MI) & 0.658 & 0.411 & 0.881 & 0.567 \\
Gonial Index (GI) & & & & 0.727 \\
\hline
\end{tabular}

contrast with Sudhakar $\mathrm{K}$ et al. in $2004^{1}$ and Sabanayagam $\mathrm{S}$ et al. in $2011^{6}$. They found that there was an association between calcium levels and hypertension condition. Hussein et al. in $2016^{21}$ had conducted a study to found out the value of bone mineral density (BMD) in hypertension patient without assessed the level of serum calcium and cortisol. They found that there was an association in the value of bone mineral density (assessed by MI and $\mathrm{GI}$ ) in untreated hypertension patient. This difference could be caused by the uncontrolled nutritional intake of calcium in the present sample. There was a possibility that even though the patient had hypertension, but if at the time of taking the sample, the patient has taken calcium supplements before, then the calcium levels would be detected with normal values. Besides, the minimal number of samples in this study could cause a non-significant correlation between calcium levels and hypertension.

In the correlation between hypertension condition and cortisol serum level, this study showed no significant difference. This result was consistent with Li X et al. in $2016^{14}$, but in contrast with the finding of Whitworth et al. in $2005^{13}$ stated that cortisol levels had an important role in blood pressure regulation. In further, Whitworth et al. ${ }^{13}$ found evidence that the elevated blood pressure seen in Cushing's syndrome due to adrenocorticotrophic hormone (ACTH) stimulated increases in cortisol secretion. They have shown that ACTH reproducibly increased blood pressure in both healthy normotensive and hypertensive subjects. Xiujuan $L$ et al. in $2016^{14}$ also had a contrast result with this present study. They found that elevated levels of serum cortisol were seen in patients with essential hypertension, and cortisol was implicated in essential hypertension genesis. Those differences in results might be due to the differences in taking cortisol samples for each patient. According to the theory, cortisol had diurnal cortisol peaks affected by the body's circadian rhythm. This circadian rhythm could cause cortisol levels to be higher in the morning (wake-up time) than at other times.

In the present study, we did not perform a screening based on body mass index, which could affect the blood's cortisol levels. Odeniyi et al. in $2015^{22}$ found that $\mathrm{n}$ that persons with BMI above 25 $\mathrm{kg} / \mathrm{m} 2$ had lower cortisol levels (113620). Bjorntorp and Rosmond, in $2000^{23}$ was stated that although cortisol excretion was increased, circulating cortisol was not high in most subjects. Indeed, although cortisol secretion is elevated, circulating concentrations may be normal or low. ${ }^{23}$

\section{CONCLUSION}

In conclusion, there was no correlation between serum calcium and cortisol level in the Mental Index and Gonial Index value in hypertension patients.

\section{ACKNOWLEDGMENTS}

None.

\section{FOOTNOTES}

All authors have no potential conflict of interest to declare for this article. This research was registered and approved by Research Ethics Committee with the registration number of 0718060916. All procedures conducted were in accordance with the ethical standards.

\section{REFERENCES}

1. Sudhakar K, Sujatha M, Babu SR, Padmavathi P, Reddy PP. Serum calcium levels in patients with essential hypertension and their first degree relatives. Indian J Clin Biochem. 2004;19 (1):21-3.

2. Krummel DA. Medical nutrition therapy in cardiovascular disease. Mahan LK, Escott-Stump S, 11th ed Ed Krause's food Nutr. 2008; 
3. Colafella KMM, Denton KM. Sex-specific differences in hypertension and associated cardiovascular disease. Nat Rev Nephrol [Internet]. 2018;14(3):185-201. Available from http://dx.doi.org/10.1038/nrneph.2017.189

4. Doumas M, Papademetriou V, Faselis C, Kokkinos P. Gende differences in hypertension: Myths and reality. Curr Hypertens Rep. 2013;15(4):321-30.

5. Gandy J. A. Stewart Truswell. ABC of Nutrition, London: BM Books (2003.f 19.95 (paperback). pp. 152. ISBN 0727916645 Br J Nutr. 2004;92(3):545.

6. Sabanayagam C, Shankar A. Serum calcium levels and hypertension among US adults. J Clin Hypertens. 2011;13 (10):716-21.

7. Hazari MAH, Arifuddin MS, Muzzakar S, Devender Reddy V. Serum calcium level in hypertension. N Am J Med Sci. 2012; (11):569-72.

8. Baumgart $\mathrm{P}$, Zidek W, Losse $\mathrm{H}$, Karoff C, Wehling M, Vetter W, et al. Obesity, hypertension and intracellular electrolytes. Klin Wochenschr. 1983;61(16):803-5.

9. Jorde R, Sundsfjord J, Fitzgerald P, Bønaa KH. Serum Calcium and Cardiovascular Risk Factors and Diseases. 2015:97:484-91.

10. Strazzullo $P$, Nunziata V, Cirillo M, Giannattasio R, Ferrara LA Mattioli PL, et al. Abnormalities of calcium metabolism in essential hypertension. Clin Sci. 1983;65(2):137-41.

11. Vargas CM, Obisesan T, Gillum RF. Association of serum albumin concentration, serum ionized calcium concentration, and blood pressure in the Third National Health and Nutrition Examination Survey. J Clin Epidemiol. 1998;51(9):739-46.

12. Carroll D, Phillips AC, Lord JM, Arlt W, Batty GD. Cortisol, dehydroepiandrosterone sulphate, their ratio and hypertension: Evidence of associations in male veterans from the Vietnam experience study. J Hum Hypertens. 2011;25 (7):418-24.

13. Whitworth JA, Williamson PM, Mangos G, Kelly JJ. Cardiovascular consequences of cortisol excess. Vasc Health Risk Manag. 2005;1(4):291-9.

14. Li X, Xiang X, Hu J, Goswami R, Yang S, Zhang A, et al. Association between serum cortisol and chronic kidney disease in patients with essential hypertension. Kidney Blood Press Res. 2016;41(4):384-91.

15. Tsuda K, Nishio I, Masuyama Y. Bone Mineral Density in Women. 2001;704-7.

16. Mussolino ME, Gillum RF. Bone Mineral Density and Hypertension Prevalence in Postmenopausal Women: Results From the Third National Health and Nutrition Examination Survey. Ann Epidemiol. 2006;16(5):395-9.

17. Ye Z, Lu H, Liu P. Association between essential hypertension and bone mineral density: a systematic review and metaanalysis. Oncotarget. 2017;8(40):68916-27.

18. Masugata H, Senda S, Inukai M, Murao K, Hosomi N, Iwado $Y$, et al. Association between Bone Mineral Density and Arterial Stiffness in Hypertensive Patients. Tohoku J Exp Med. 2011;223 (2):85-90.

19. llić K, Obradović N, Vujasinović-Stupar N. The relationship among hypertension, antihypertensive medications, and osteoporosis: A narrative review. Calcif Tissue Int. 2013;92 (3):217-27.

20. Kosch M, Hausberg M, Barenbrock M, Posadzy-Malaczynska A, Rahn $\mathrm{KH}$, Kisters $\mathrm{K}$. Increased membraneous calcium concentrations in primary hypertension: a causal link to pathogenesis? J Hum Hypertens. 2001;15(1):37-40.

21. Hussein, Marwa., Fatah A. The Effect of Hypertension and Beta -Blocker Antihypertensive Drug on Bone Mineral Density Value At the Mandibular Cortex in Mental and Gonial Regions in Hounsfield Unite Using Computed Tomographic Study University of Baghdad - College of Dentistry Assist. 2016;1 (38):33-47.

22. Odeniyi IA, Fasanmade OA, Ogbera AO, Ohwovoriole AE. Body mass index and its effect on serum cortisol level. Niger J Clin Pract. 2015;18(2):194-7.

23. Björntorp $P$, Rosmond R. Obesity and cortisol. Nutrition. 2000;16(10):924-36. 